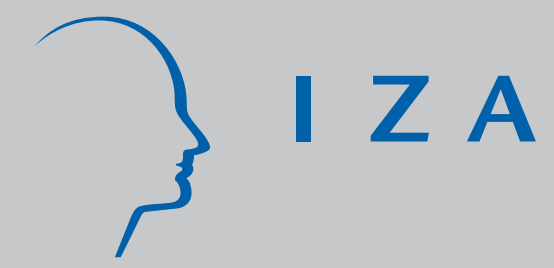

IZA DP No. 40

Empirical Findings on the Swiss Migration Experience

Thomas Straubhaar

Stefan M. Golder

April 1999 


\title{
Empirical Findings on the Swiss Migration Experience
}

\author{
Stefan M. Golder \\ Thomas Straubhaar
}

Discussion Paper No. 40
April 1999

IZA

P.O. Box 7240

D-53072 Bonn

Germany

Tel.: +49-228-3894-0

Fax: +49-228-3894-210

Email: iza@iza.org

This Discussion Paper is issued within the framework of IZA's research area Mobility and Flexibility of Labor Markets. Any opinions expressed here are those of the author(s) and not those of the institute. Research disseminated by IZA may include views on policy, but the institute itself takes no institutional policy positions.

The Institute for the Study of Labor (IZA) in Bonn is a local and virtual international research center and a place of communication between science, politics and business. IZA is an independent, nonprofit limited liability company (Gesellschaft mit beschränkter Haftung) supported by the Deutsche Post AG. The center is associated with the University of Bonn and offers a stimulating research environment through its research networks, research support, and visitors and doctoral programs. IZA engages in (i) original and internationally competitive research in all fields of labor economics, (ii) development of policy concepts, and (iii) dissemination of research results and concepts to the interested public. The current research program deals with (1) mobility and flexibility of labor markets, (2) internationalization of labor markets and European integration, (3) the welfare state and labor markets, (4) labor markets in transition, (5) the future of work, and (6) general labor economics.

IZA Discussion Papers often represent preliminary work and are circulated to encourage discussion. Citation of such a paper should account for its provisional character. 


\title{
ABSTRACT
}

\section{Empirical Findings on the Swiss Migration Experience}

Switzerland has experienced a substantial influx of immigrants over the last 50 years after World War II, which has led Switzerland to have among the highest share of foreigners in population among all OECD countries. This paper analyses the migration experience of Switzerland. The analysis centres around two main issues: the economic effects of migration and the labour market performance of immigrants. Two main results emerge from our study. First, as a result of the shortcomings of the Swiss migration policy, immigrants tend to have a negative impact on the Swiss economy. Second, the analysis of the labour market performance shows that there are substantial discrepancies in the performance between immigrants from different countries of origin. Immigrants from Northern European countries largely outperform immigrants from Southern European and Non-European countries. On the basis of the empirical analysis, this study finally outlines some reform options for the Swiss migration policy.

JEL Classification: D33, F22, J24, J31, J61

Keywords: Factor income distribution, international migration, labor productivity, wage differentials, immigrant workers

\author{
Thomas Straubhaar \\ University of the Bundeswehr Hamburg and CEPR \\ Holstenhofweg 85 \\ 22043 Hamburg \\ Germany \\ Tel: +494065412850 \\ Fax: +494065412850 \\ e-mail: thomas.straubhaar@unibw.hamburg.de
}

\footnotetext{
"An earlier version of this paper was presented at the CEPR Conference „European Migration: What do we now?", 14.-15. November 1997, Munich, Germany, aand the European Research Conference „Migration and Development", 21.-26. April 1998, Espinho, Portugal. Helpful comments and suggestions by Klaus F. Zimmermann, Thomas Bauer, Christoph Schmidt and George Sheldon as well as by the participants of these conferences are grateful acknowledged. Any remaining errors and omissions remain ours.
} 


\section{Introduction}

Switzerland has a long tradition of immigration which started in the second half of the last century. Since the beginning of this century, Switzerland has experienced substantial immigration. Especially during the last 50 years after World War II, a massive inflow of immigrants, mainly labour migrants due to shortages on the labour market, has led to a share of foreigners in total population of one fifth and a share of foreign workers in overall employment of one fourth in 1998. Together with Luxembourg and Australia, Switzerland therefore has by far the highest share of foreigners in total population among all OECD countries. Analysing the Swiss migration experience from an economic point of view can therefore help to explain economic developments in Switzerland and provide information on the effectiveness of the Swiss migration policy.

The paper is structured as follows. In the second section, we give a short overview on the Swiss migration experience and highlight the main characteristics of the Swiss migration policy. In the third section, we analyse the economic effects of migration on the Swiss economy. There are four issues that are analyzed, namely growth, business cycle, structural and distributional effects arising from immigration. In the fourth section, we turn to the analysis of the labor market performance of immigrants. We provide empirical evidence on the employment as well as earnings performance of immigrants compared to natives. Finally, in the fifth section, we sketch a reform proposal for the Swiss migration policy.

\section{Migration to Switzerland - Experience and Policy}

The development of the Swiss economy in the last 150 years since the foundation of the Swiss federal state, has been markedly influenced by the immigration of foreign workers. The historical experience of migration to Switzerland can be subdivided in three main periods. The first period lasted until 1963 and was characterised by a liberal admission policy, with the exception of the time from 1914 until 1945. The second period started in 1963 when the Swiss government introduced restrictions on the admission of immigrants. The third period began in 1991, when the Swiss government introduced an admission policy which was based on country of origin considerations.

\subsection{Liberal admission policy}

With the start of the industrialisation process in the middle of the last century, a substantial demand for foreign workers developed in Switzerland. The comparatively attractive jobs as well as the complete freedom of movement and settlement led to a large inflow of immigrants to Switzerland. As a result, the number of foreigners living in Switzerland increased markedly to 
600 '000 persons or $15.2 \%$ in total population in 1914. Until World War I and because of the strong federal structure in Switzerland, the authority on migration policy was in the hands of the state governments and not the federal government.

The outbreak of World War I led to an end of the liberal admission policy and to the introduction of a restrictive migration policy that lasted until the end of World War II. The introduction of admission restrictions revealed that the Swiss migration policy was guided by labour market considerations, as an important criteria for the admission of immigrants was the absorption capacity of the Swiss labour market. As a result of the restrictive admission policy, which lasted for the two World Wars and the Great Recession, the stock of foreigners dropped to a low of 224'000 foreigners living in Switzerland or 5.2\% of total population in 1941.

In 1925, the authority on migration policy was passed to the federal government by a plebiscite, enabling the federal government to enact laws on foreigners and immigrants. This led to the Federal Law of Abode and Settlement (ANAG) in 1931, which still forms the basis of the Swiss foreigner and migration policy today, although substantial modifications were introduced over time. The restrictive migration policy was characterised by the aim to counteract the inflow of a large amount of foreigners, to avoid the import of unemployment and to implement a selective and limited recruitment of foreign workers corresponding to the needs of the Swiss labour market.

The ANAG led to the introduction of a number of different residence categories, which can be grouped according to the validity of the residence permit. Currently they comprise five (main) residence categories: seasonal permit, short stayer permit, commuter permit, annual permit and residence permit. The favourable economic conditions and the fast recovery after World War II led to shortages on the Swiss labour market which in turn induced a substantial demand for immigrant workers. During this period the admission policy was liberal, which reflected the goal to meet the expanding labour demand. ${ }^{1}$ Over the period from 1950 to 1960, the number of foreigners living in Switzerland rose from $285^{\prime} 000$ to $585^{\prime} 000$ persons, which corresponded to an average annual growth rate of the foreign residential population of $7.4 \%{ }^{2}$

As already pointed out, the Swiss migration policy was and still is largely dominated by economic interests, mainly labour market considerations. The main idea after World War II was that immigrants should help to smooth business cycles on the labour market, with immigration of foreign workers during economic upswings and remigration during downswings, thereby stabilising the employment of natives. As it was believed that immigrants would come to Switzerland only

\footnotetext{
1 Chronic labour shortages occurred mainly in those sectors, which were left by Swiss workers because of lacking attractivity [Schwarz (1988)].

2 The foreign residential population includes foreigners with an annual or a residence permit.
} 
temporarily, thereby implying a high 'rotation' of foreign workers, this goal could easily be achieved. Migration policy could thus be used as an instrument for labour market and business cycle policy.

Over time it turned out, however, that a large share of the inflow of foreign workers was not temporary but permanent. The combination of a liberal admission of immigrant workers during the 1950s and 1960s together with a declining rotation led to a substantial increase in the stock of foreigners living in Switzerland. As a result of the focus on the recruitment of foreign workers in the post-war period, Hoffmann-Nowotny/Kilias (1979: 55) concluded that the Swiss migration policy during this period could be characterised as "... maximizing immigration while minimizing the immigrants chances of integration".

\subsection{Restricted admission}

The growing stock of foreigners as well as the inflationary pressures of the booming Swiss economy intensified the claims for public interventions to control the inflow of new immigrants towards the end of the 1950s. In 1963, the Swiss government - for the first time after World War II - introduced measures to control and limit the inflow of new immigrant workers, with ceilings on immigrant worker employment applying at the company level. These measures turned out to be largely ineffective in limiting the inflow of foreign workers, with the share of foreigners in total population rising from $10.8 \%$ in 1960 to $17.2 \%$ in 1970 . The failure of this stabilisation policy as well as the growing discontent among Swiss citizens about the increasing number of foreigners, which was articulated in the second "foreignerisation initiative", led to a major turnaround in the Swiss migration policy. In 1970 the Swiss government introduced an immigration quota system with an annual maximum number of admittances for each residence category. ${ }^{3}$ The aim of this new policy was to control and limit the overall inflow of foreigners and to stabilise the share of foreigners in total population.

Following the economic downswing in the 1970s, which led to a decrease in immigration, the upswing at the beginning of the 1980s triggered again a substantial influx of immigrant workers and together with other forms of migration such as family and refugee migration, the share of foreigners in total population rose to $18.1 \%$ in 1990 . This steady increase in the number of foreigners living in Switzerland, together with a shift in the structure of the immigrants in terms of migration motives as well as countries of origin led to a reorientation of the Swiss migration policy at the beginning of the 1990 s. $^{4}$ Before turning to this issue in the next section, it is worthwhile to briefly summarize the main

No quotas were introduced for residence permits and commuter permits.

While the share of immigrant workers from neighbouring countries was around 95 per cent in 1950, this share has declined to around 50 per cent in 1998. A similar pattern can be observed for the foreign residential population. Analogous to this shift in the countries of origin, we can observe a shift in migration motives, with 
goals of the Swiss migration policy.

The main goal of the Swiss migration policy is the stabilisation goal. Although the term 'wellbalanced' allows for some scope of interpretation, it is usually understood as 'relative stabilisation'. The integration goal is used explicitly only since 1986 and refers mainly to measures that had already been adopted before 1986. The labour market structure goal implies that the allocation and recruitment of immigrant workers should be guided by the sectoral and regional specific demand for certain types of foreign labour. The business cycle goal had already been adopted in 1963, when the first restrictions on the immigration of foreign workers were implemented. While in the 1960s the basic idea was to use migration policy to counter inflationary pressures, in the 1970s it was to counter the recession.

Aside from these explicit goals of the Swiss migration policy, there are also three implicit goals. Already in 1949 the government started to give priority to domestic workers to fill job vacancies. As a result, work permits can only be issued to immigrant workers if there is no equivalent domestic worker who is willing and able to do that specific job. The regional policy goal, i.e. the support of peripheral regions, implies that these regions should receive a larger share of the immigration quotas relative to their size, in order to be able to stabilise population and improve economic prospects. Finally, the goal to preserve the prevailing economic structure, is mainly achieved with the recruitment of seasonal workers.

\subsection{Three circle admission policy}

The need for reform of the Swiss migration policy at the beginning of the 1990s can be documented with at least three arguments. First, the existing regulations did not adequately take into account the qualitative needs of the Swiss labour market, thus leading to a disparity between labour demand and labour supply. This issue can be illustrated by the fact that the large majority of long term foreign residents has entered Switzerland as seasonal workers.5 As these immigrants are by and large low-skilled, they have not only contributed to an oversized industrial sector but also to a much higher share of unemployed foreigners compared to natives.

Second, Western European countries are confronted with an increasing international migration pressure, not only because of the problems in the Balkan States, but also because of the opening of borders in Eastern Europe as well as because of the demographic developments in the Near East and Northern Africa. Third, the implementation of the Common European Market at the beginning of

the share of non-labour migration having increased from merely 15 per cent in 1960 to more than 65 per cent in 1998. [see Golder (1999)]. 
1993 as well as the 'No' of the Swiss electorate in December 1992 to join the European Economic Area have led to an outsider role of Switzerland in the integration process in Europe. As a result, the Swiss economy is not only disadvantaged with respect to its European competitors, but also loses attractiveness for those foreigners it intends to attract, because of their qualifications as well as their cultural proximity. ${ }^{6}$

The new concept of a three circle admission policy aimed at two main goals. First, Switzerland should become more closely incorporated in the European integration process. Second, the increased global migration pressure should be tackled. At the heart of the new approach was the so called 'three circle admission policy'. In contrast to the prevailing system, the new policy defined three layers of admission according to geographical-political areas. Within the first circle, complete freedom of movement with the member countries of the European Economic Area is aimed at. As regards the second circle, which includes other industrial countries such as the United States, Canada, Australia and New Zealand, there should be only limited recruitment of immigrant workers. Finally, there should be no recruitment of immigrant workers from all other countries which are collected in the third circle.

Recently, a report by the commission on migration policy has outlined a new migration policy framework for Switzerland, which was approved by the government. ${ }^{7}$ This report by and large corresponds to the reform proposal for the Swiss migration policy put forward in Golder (1997b), which will be discussed in more detail in section 5. The main elements of this approach are a switch from the three circle to a two circle migration policy. Within the first circle and in accordance with the existing policy, free movement of labour between the European Economic Area and Switzerland is aimed at. For the second circle, a point system to screen new immigrants in combination with an overall immigration quota is suggested for all other countries.

\section{Economic effects of migration}

As already pointed out in the introduction, there are a number of channels through which immigration can influence the host country's economy. In what follows we will consider macro- as well as microeconomic effects of migration. While analysis of the former is related to growth, business cycle, and structural effects, the latter is concerned with allocational and distributional effects of migration.

Haug (1995).

Expertenkommission Migration (1997). 


\subsection{Migration and Growth}

Migration influences the per capita endowment of capital and therefore also capital accumulation and economic growth. As a result of the influx of immigrant workers, capital intensity, i.e. the per capita stock of capital in the receiving country, decreases and accordingly also average labour productivity. A negative effect on the welfare of natives may result, if there is a positive relationship between the capital intensity of the economy and technological progress. If technological progress is governed by capital intensity, it will be slowed down by migration induced factor price changes. This will also hamper structural change, leading to negative effects on productivity and income growth. This result has to be qualified, however, if immigration increases labour market flexibility. Finally, it must be noted that the growth effects of migration also depend on the economic structure of the receiving country as well as on the "quality" of the immigrants. These effects will be the better the larger the economies of scale in production, the less technological progress depends on capital intensity and the larger the elasticity of substitution between skilled and unskilled labour. Intensive growth, i.e. per capita growth, is also more likely the higher skilled immigrants are and the more favourable their demographic composition is.

In his empirical analysis of the growth effects of migration in Switzerland, Schwarz (1988) estimated a neo-classical production function for the period from 1962 to 1986 with four factors of production: native labour, foreign labour, capital and exogenous technological progress. The partial production elasticities did not turn out to be statistically significant, which indicates that the assumption of economies of scale had to be rejected. Nevertheless, the marginal production elasticities differed markedly between immigrants and natives. The average marginal productivity of Swiss workers was twice as high as that of immigrant workers. Based on the estimation results of the national production function, Schwarz calculated the contribution of foreigners to growth, to per capita growth and to productivity growth. The results can be summarised as follows: In the period from 1962 to 1986 the average annual growth rate amounted to $2.4 \%$. Growth was mainly driven by technological progress $(1.6 \%)$ and capital $(0.7 \%)$, whereas the contribution of native and immigrant labour to growth was poor with $0.3 \%$ and $0.2 \%$ respectively. The weak but positive growth effect of immigrant labour was mainly caused by the high growth rate of the number of immigrant workers. This quantitative effect was by and large compensated by a lower elasticity of production of immigrant workers.

The average annual per capita growth rate between 1962 and 1986 was $1.7 \%$. The contribution of Swiss employees was slightly negative with $-0.1 \%$ p.a., as the negative effect of a reduction in the participation rates outweighed the positive effect of population growth. Although 
immigrants made up only about $17 \%$ of total population, their growth reducing effect was twice as large as that of Swiss workers, with $-0.2 \%$ p.a. This can be explained on the one hand by the substantial reduction in the participation rate as a result of a 'chain migration effect' ${ }^{8}$, and by a low elasticity of production on the other hand. As a result, only capital and technological progress had a positive impact on per capita growth. According to the estimates of Schwarz, productivity increased on average by $1.9 \%$ between 1962 and 1986. In contrast to immigrant workers $(-0.1 \%)$, the contribution of Swiss workers was still slightly positive $(0.049 \%)$. Productivity growth was therefore mainly based on capital accumulation and technological progress. The negative effect of immigrant workers on productivity indicates that the employment of immigrant workers has mainly contributed to structural preservation and a slowdown of technological progress. ${ }^{9}$ It has to be mentioned, however, that Schwarz did not base his analysis on a microeconomic framework. Data on industry level employment indicates that immigrant workers had already been underrepresented in highly productive industries since the early 1960s and overrepresented in peripheral, low productive industries. Accordingly, the significantly lower marginal productivity of immigrant workers can be attributed not only to their lower skill level, language barriers etc., but also to their allocation to low productive jobs.

\subsection{Migration and Business Cycles}

Migration leads to an outward shift of the production possibility frontier. The employment of immigrant workers increases production and reduces excess demand on the labour and goods market. Additionally, wage and price increases can be dampened with immigrant worker employment. If foreigners exhibit a marginal propensity to consume which is smaller than one, then the ratio between consumer demand and supply decreases. The pressure on price increases is therefore the smaller, the larger the savings rate of immigrants is. The population increase induces a rise in the demand for goods, and if full capacity utilisation is assumed this in turn implies an expansion of the infrastructure. If supply is price inelastic, this will lead to a price increase. The timing of supply and demand effects is therefore important. If immigrant workers are employed from the beginning, the price increase can be reduced if consumption demand takes up with a lag. In an empirical study of the Swiss inflation process of the years 1948 to 1966, Rossi/Leighton (1971)

\footnotetext{
8 Underlying the migration chain effect is the observation that foreign workers usually immigrated alone, with the goal to accumulate enough money to build up an existence in the home country within a short period of time, but then settled permanently in the host country, triggering a chain of additional immigration as result of family reunification (see Boehning (1972, 1984).

9 Blattner/Sheldon (1989) confirm these results. Their growth-accounting analysis reveals also that foreign labour can help to support extensive growth, but this occurs at the cost of productivity and per capita output growth.
} 
concluded that excess demand influenced prices indirectly via higher marginal costs. Nevertheless, the rise in productivity reduced this effect increasingly over time. ${ }^{10}$

Immigration can have procyclical effects if immigrants are triggered in a boom period, thereby leading to an acceleration of economic activity. The same holds for a recession period when emigration takes place, thereby reinforcing the contraction of economic activity via the demand effect. There are two ways how migration can stabilise employment. First, overall employment can be stabilised if the labour market structures become more flexible as a result of immigration. Second, migration could work as a cyclical buffer leading to a stable intertemporal employment pattern of native workers by absorbing cyclical employment fluctuations through changes in immigrant worker employment.

In this context, two central elements of the Swiss migration policy, namely the 'rotation principle' and the related 'cyclical buffer function' of immigrants have to be mentioned. According to the rotation principle, it was assumed that the typical immigrant was young and single. Furthermore, it was believed that it was the goal of these immigrants to accumulate financial resources and then to return to their home countries. Immigration was therefore regarded as temporary and large in- and outflows were expected accordingly, i.e. a high rotation. Closely related to the rotation principle was the cyclical buffer function of immigrant workers. In a situation of a cyclical downturn, the rotation of foreign workers together with admission restrictions on the inflow of new immigrants would allow a stabilisation of the employment of native workers. This could be achieved at the cost of fluctuations in the employment of immigrants.

Although the rotation has tended to decline since 1970, there are still substantial dynamics today. In 1995, immigration amounted to $3.7 \%$, emigration to $4.4 \%$ and gross migration to $8.0 \%$ of the average stock of foreigners. The rotation thesis therefore seems to remain valid. Schwarz (1988) empirically tested the effect of migration flows on business cycles for Switzerland. His results can be summarised as follows. During boom periods, immigration and net migration, i.e. immigration emigration, are particularly large, during a cyclical downturn particularly small. With respect to immigration and net migration, the cyclical buffer function of immigrants seems to be confirmed. Emigration is also rather high during cyclical downturns, although not statistically significant. The same result holds for gross migration. Therefore, there seems to be an negative correlation between immigration and emigration during up- and downswings.

Of special interest is the cyclical buffer function of foreigners during recession years. The recession of the mid-1970s hit Switzerland more intensively than other Western European countries.

10 See also Chiodi-Ferro (1994). 
Between 1974 and 1976, employment decreased by almost 250'000 persons which corresponded to almost $7.6 \%$ of total employment. This reduction in employment was mainly borne by immigrants, as the reduction in foreign worker employment was around six times larger than for Swiss workers. With respect to the period from 1973 to 1977 , employment of Swiss workers declined by only $1.1 \%$ compared to $25.5 \%$ for foreigners. Overall, $75 \%$ of the decline in employment was borne by the nonresident population, $17 \%$ by the resident population, i.e. Swiss and immigrants with a residence permit, and only $8 \%$ by an increase in the Swiss unemployment rate. ${ }^{11}$

The recession at the beginning of the 1980s had a much smaller impact on employment in Switzerland. Although employment declined between 1982 and 1984, this decrease amounted to merely $2.1 \%$ of total employment. The extent to which foreign workers have served as cyclical buffers during this recession is more difficult to evaluate, because the number of employed Swiss declined by $2.9 \%$ during this period, while the number of employed foreigners declined only in 1983 with an overall increase of $0.8 \%$ between 1982 and 1984. This is remarkable as immigrants are not only characterised by a lower skill level compared to natives but also by a more disadvantageous sectoral distribution than natives. ${ }^{12}$ These results have to be qualified, when the employment performance of immigrants compared to natives is considered which reveals that the unemployment rate for immigrants was substantially higher than for natives (see section 4).

Two main reasons for the diverging development between the recession of the 1970s and the 1980s, i.e. the decreasing importance of the cyclical buffer function of immigrants, can be put forward. ${ }^{13}$ First, the stock of manoeuvrable foreign workers dropped substantially over that period, as the share of immigrants holding a residence permit increased from $30.8 \%$ in 1973 to $51.7 \%$ in 1981. Second, there were substantial demographic differences between Swiss and foreign employees. Retirements between 1982 and 1984 amounted to 3.3\% of the employed for Swiss and to 0.8\% for foreigners. ${ }^{14}$ As a result, retirements of Swiss employees exceeded the decline in employment, whereas the number of retirements and the decline in employment for foreign employees just balanced out. As there has not been a reduction in employment, it is obvious to assess the cyclical buffer function of foreigners by means of unemployment figures, which reveal that foreigners were hit much harder by the recession of 1980s than natives (see also section 4).

\subsection{Migration and Structural Change}

The recession of the mid-1970s emphasised not only the large regional disparities, but also the

OECD (1985).

Schwarz (1985).

See also Fischer/Straubhaar (1996).

Schwarz (1988). 
problems related to regions which were depending on one or very few dominating industries, such as the 'watch region'. As already pointed out, the Swiss migration policy aimed at influencing the regional and sectoral development. The policy targets suggest that migration policy has by and large hindered structural change with its strategy to protect industries and to support peripheral regions. This section evaluates the effect of migration on structural change.

The Swiss migration policy is indeed used as an instrument for regional policy, as the allocation of state quotas for foreigners with an annual or seasonal permit is biased in favour of peripheral and low wage states. This allocation practice is not consistent with overall economic efficiency, but can be justified with regional policy arguments. Whether the goals of regional policy have really been achieved, depends on two preconditions that have to be satisfied: first, the allocation of immigrant workers to states must be influenced on a sustained basis and second, immigrant worker employment must be positively related to economic performance. To evaluate the first precondition, we have to distinguish the different residence categories for immigrants. Flexibility and control is large for immigrants with seasonal permits as they are not only subject to quotas but usually also tied to their employer for the duration of their stay. Peripheral regions can therefore be treated preferentially with the allocation of immobile seasonal workers. This result holds only in the short run, however, as seasonal workers may transform their seasonal permits into annual permits after having worked 36 months consecutively in Switzerland which gives them the freedom of movement and settlement everywhere in Switzerland. Additionally, seasonal workers usually exhibit lower skill levels compared to the rest of the immigrant population. It is therefore questionable whether seasonal workers can help to promote growth and welfare in peripheral regions.

In contrast to seasonal workers, immigrants with an annual or residence permit are free to move, which makes it impossible to influence and control the regional allocation of these immigrants. Evidence shows that movements from the low-wage peripheral to the high-wage core regions dominate the migration pattern within Switzerland, which leads to a net outflow of immigrants from the periphery. ${ }^{15}$ It is therefore not possible to allocate immigrants to peripheral regions on a sustained basis. To achieve this, additional barriers to mobility would have to be introduced. ${ }^{16}$

\subsection{Allocational Effects of Migration}

Based on the assumption of a neo-classical framework with homogenous and elastic labour supply and demand, migration can be understood as an arbitrage process to eliminate wage

Schwarz (1988).

As a result of this analysis, an evaluation of the second precondition becomes superfluous. Nevertheless, the analysis in section 3.1 showed that there is a negative relationship between foreign worker employment and economic development on the national economic level. 
differentials. Migration in turn leads to an increase in total employment and a reduction in the employment of native workers. Although national income grows, it is possible that per capita income may fall, as the additional income has to be shared with the new immigrants. While the income of native workers falls, the return to capital rises. As a result, the income, employment and distributional effects depend on the amount of immigration as well as on the demand and supply elasticities in the labour market. One can think of several extensions of this basic model. First, demand effects resulting from migration could be considered. Second, we could think of a two good model, with one good produced capital intensively and the other labour intensively. Third, we could extend the neo-classical model in order to account for capital mobility. Fourth, the neo-classical assumptions of homogenous labour and a flexible labour market could be dropped. These extensions lead to less clear outcomes with respect to the wage as well as the employment effects for natives.

Kugler/Spycher (1992) studied whether immigrants and natives are complements or substitutes. Their results show that skilled immigrants and natives are complements, while unskilled natives and immigrants are substitutes. The studies by Bürgenmaier/Butare/Favarger (1992) and Butare/Favarger (1992) analyse whether labour and capital are substitutes or complements in the production process. They found a complementary (substitutional) relationship between capital and foreign (native) labour in Switzerland for the period from 1950 to 1986. At first glance, these results seem to contradict the traditional view of a complementary (substitutional) relationship between skilled (unskilled) labour and capital. This contradictory result can at least in part be attributed to the aggregation of different sectors using different shares of skilled and unskilled labour. As some sectors use mainly skilled labour while others use mainly unskilled labour, it is difficult to predict the relationship between elasticities which are based on regressions on aggregated variables. Additionally, it is likely that the demand for capital in those sectors that employ a large share of immigrants increases at a lower rate due to the labour intensive production technology. This allows investments in those sectors, in which the substitution between labour and capital is more expensive (and in which the share of natives is larger).

Bürgenmaier/Butare/Favarger (1992) also show that there is a marked correlation between changes in elasticities of complementarity and substitution on the one hand and the stock of immigrant workers on the other hand. Complementarity between capital and foreign labour diminished considerably from 1950 until 1964, then it increased again until 1977 and subsequently stabilised. Accordingly, the degree of complementarity and the stock of immigrant workers seems to move inversely. In contrast to the above mentioned studies, Kohli $(1993,1997)$ conducts his analysis on the allocational effects of migration in an open economy model. Kohli emphasised that studies 
based on closed economy models neglect possible interactions between international factor movements and foreign trade. His empirical analysis is also based on a production theory framework and covers the years 1950 to 1986. The results indicate that immigration may have substantial displacement effects if there is a downward wage rigidity. In the case of flexible wages, increased migration will decrease the income of native workers only slightly. Capital owners in contrast, as predicted by theory, benefit from migration. Imports and immigrant workers are found to be complements in the sense that more immigration leads to more imports.

\subsection{Distributional Effects of Migration}

The main economic justification for government action is usually seen in the provision of nonmarketable goods for its residents. It is therefore legitimate to ask for an appropriate financing contribution by immigrants. To finance current costs of public services, taxes and fees can be levied from natives and immigrants alike. Additionally, immigrants would have to contribute to the existing capital stock with an entry fee or a similar levy. ${ }^{17}$ In general, immigration results in positive effects for natives, if the sum of taxes, fees and social security contributions is larger than the sum of fiscal and social transfers, i.e. monetary transfers, and the costs of the marginal use of public and club goods, i.e. real transfers, by immigrants. ${ }^{18}$

In empirical studies based on cross-sectional data from the 1990 Swiss consumer survey, Weber (1993), Straubhaar/Weber (1994) and Weber/Straubhaar (1994) estimated the transfer balance for natives and immigrants (foreigners with an annual or a residence permit). They used three main budget categories, namely social transfers (public social security insurance, public welfare programs and monetary transfers for redistributive purposes), producer side public transfers (indirect taxes and subsidies) and public and club goods. Their analysis indicates that natives gained from the presence of resident foreigners in 1990. The net transfer per foreign resident household in favour of the Swiss population amounted to approximately 1'770 USD. The total financial benefit for the Swiss in 1990 therefore sums up to 464.1 Mio USD, which implies that the immigrant population has relieved the government budget by approximately 464 Mio USD.

A more detailed analysis of the transfer balance shows that the dominant role favouring the Swiss is played by social security insurance and old age pensions in particular (approximately 3'000 USD). Despite the relatively higher average expenditures for foreign resident households (approximately 260 USD), the budget incidence for producer side public transfers results in a positive net effect for the Swiss population (approximately 280 USD). With respect to public and

See Boehning (1976).

For more details see Weber (1993). 
club goods, however, there is a net transfer to foreign resident households. The average expenditure surplus of approximately 1'560 USD which burdens the Swiss population is only slightly reduced by average contributions by immigrants (approximately 50 USD). The analysis by Straubhaar and Weber therefore reveals that the provision of public and club goods represents the main financial burden caused by immigrants. The positive effect for natives resulting from social transfers and producer side public transfers is significantly reduced by the expenditure surplus in favour of immigrants resulting from the provision of public and club goods.

The overall positive budget effect resulting from migration has to be qualified on several grounds. A first objection to the above results is that they are exclusively based on cross sectional data. To get a more accurate picture of the transfer balance, it would be necessary to perform a longitudinal analysis. One could also think of an analysis within a generational accounting framework, where contributions and benefits over the life cycle are considered. As a result of the cross sectional nature of the analysis, the structure of households considered influences the results substantially. At present, immigrants exhibit a more favourable demographic structure compared to natives. This is likely to change within the next 30 years. Additionally, unemployment rates remained well below 1\% until 1990 (1990: Swiss 0.4\%, immigrants 0.9\%, overall 0.5\%). This has changed dramatically since the beginning of the 1990s, with unemployment rates for immigrants being considerably higher than for natives (1995: Swiss 3.2\%, immigrants 8\%, overall 4.2\%). It is therefore likely that the positive budget effect for natives has diminished over the last few years.

Nevertheless, there are also some factors that suggest an even larger gain from migration. First, immigrants with seasonal permits are not considered in the analysis. This group is, however, especially likely to pay taxes and contribute to social security, while at the same time benefits from monetary and real transfers can be expected to be small. Second, return migration after retirement might relieve health care systems, as these expenditures rise sharply with increasing age.

\section{Labour market performance of immigrants}

While the previous section was concerned mainly with the economic effects of migration, in this section we focus more closely on the individual migrants, as we analyse the labour market performance of immigrants. To provide a comprehensive analysis of the labour market performance, the earnings as well as the employment performance of immigrants is studied. So far, there have only been very few studies on this issue for Switzerland [see Golder (1997, 1998, 1999), Golder/Straubhaar (1998), Maechler (1993)]. ${ }^{19}$ This can partly be explained by the lack of adequate

19 The following discussion is based on the studies by Golder and Golder/Straubhaar. A major shortcoming of the study by Maechler consists of the limitation of the analysis to natives and foreigners, thereby neglecting the 
data. This gap has been closed with the introduction of the Swiss Labour Force Survey (SLFS) in 1991. The SLFS provides important internationally comparable information on employment in Switzerland. Approximately 18'000 randomly selected persons from the official telephone register are interviewed every year. For the 1995 wave of the SLFS, on which the analysis of this paper is based on, an additional 14'000 persons were interviewed to allow for a more disaggregated analysis. The SLFS comprises a total of 500 questions, with each person asked around 100 questions on labor market related topics as well as on their socio-demographic profiles (e.g. sector, employment status, tenure, job mobility, job search, education, earnings). The survey is restricted to persons of the resident population aged at least 15 years, i.e. Swiss and immigrants holding a residence or an annual permit [for more details see Swiss Federal Statistical Office (1996)]. ${ }^{20}$

\subsection{Theoretical framework}

Economic research on the labour market performance of immigrants respectively is usually based on the findings of human capital theory. ${ }^{21}$ The results of this research can be summarised as follows: Based on the idea that migration is an investment decision, the process of migration can be understood as an investment, with an income reduction at the beginning, resulting from the costs of migration as well as from a potentially lower initial salary in the host country, and the returns, i.e. higher income or better living conditions, accruing eventually over time. Economic agents are therefore calculating, depending on their individual abilities, the net present value of expected earnings in various regions. Migration will take place in this framework, if the net present value in the target country is higher than in the source country, taking into account the costs of migration.

At least six factors can be identified that determine the labour market performance of immigrants. First, the performance depends on the selection of immigrants, i.e. whether immigrants represent a positive or a negative selection of the source country's population. This issue has been suject to intensive theoretical as well as empirical debate [see Chiswick (1978, 1994) and Borjas (1985, 1989, 1991)]. Second, it depends on the international transferability of human capital. The existence of a positive or negative selection does not suffice to determine the labour market performance of immigrants. Their performance is also influenced by the extent to which the human capital acquired in the source country is transferable to the host country.

Third, an additional important determinant of the labour market performance is the immigrants'

influence of country of origin differences in the labour market performance of immigrants. Additionally, the study by Maechler is concerned only with the earnings performance of immigrant workers. 
expected duration of stay in the host country. ${ }^{22}$ This aspect is especially relevant for the determination of the earnings assimilation of immigrant workers, as a longer expected duration of stay will most likely lead to larger investments in host country specific human capital. Fourth, and equally important for the evaluation of immigrant earnings over time is the age at immigration. ${ }^{23}$ This issue centres around the question whether intergenerational performance differences among immigrants can be expected.

Fifth, there are a number of economic, demographic as well as political factors which influence the size and composition of the migration flow. Together with the specific labour demand for foreign workers in the host country, these factors affect the labour market performance of immigrant workers. Finally, immigrant workers might be subject to labour market discrimination which is likely to have an impact on their performance. Two interdependent approaches could be used to assess the degree of discrimination: the theory of wage discrimination and the theory of labour market segmentation. $^{24}$

\subsection{Stylised Facts}

In what follows, we briefly want to draw a statistical portrait of immigrants. We start with the demographic characteristics of immigrants. Table 1 reveals four important demographic characteristics of immigrants compared to natives. First, the weight of traditional guest-worker countries in Southern Europe (mainly Italy and Spain) increases, the older the immigration cohort is.

First, it is apparent that with an increasing duration of stay, the weight of those countries of origin that formed the first immigration waves increases. Almost $75 \%$ of all foreigners who lived at least 15 years in Switzerland in 1995 came from Italy, Spain and Germany. Second, a shift in the countries of origin to countries like Portugal, Turkey, the former Yugoslavia and other NonEuropean countries has taken place over time, especially since the upswing of the 1980s. Since the end of the 1980s, immigration from Northern European countries increased once again. Third, and related to the previous issue, the increasing share of immigrants from Non-European countries reflects the refugee movements to Switzerland that started mainly in the 1980s. Fourth, the age at immigration has increased over time, i.e. members of younger immigration cohorts enter later. One explanation for this development can be found in the decreasing share of generally low-skilled guest workers and the increase in immigration of higher skilled immigrants. Accordingly, the latter will be comparatively older than the former. 
Turning to the qualification structure of immigrants, three points are noteworthy in Table 2. First, for male as well as for female, there are significant nationality specific differences in the skill level, with the most (least) favourable profile for immigrants from Northern European (NonEuropean) countries. Immigrants from Northern European countries even seem to outperform natives in terms of skill profiles. Second, there is a noticeable heterogeneity in the qualification structure for immigrants from Non-European countries, which is mainly due to the high level of aggregation within this nationality group. Finally, aside from nationality specific differences, there are also gender specific differences in the qualification structure.

\section{- TABLE 2 -}

After this brief discussion of a number of important demographic characteristics, we now turn to the more specific discussion of the labour market performance of immigrants, i.e. the employment and the earnings performance. With respect to the latter, Tables 3 and 4 provide some descriptive statistics on the employment as well as the unemployment performance of immigrants. In Table 3, we distinguish between participation rates and employment level in our analysis. As can be seen, while there are substantial gender specific differences in employment rates, Table 3 reveals no big differences, neither for men nor for women, when immigrants and natives are compared. It is not possible, however, to draw any conclusions on the employment performance from these results, as the calculation of employment rates is based on employable as well as employed persons. If in contrast the employment rate is considered, i.e. the ratio of employed to employable persons aged 16 to 64 , male and female immigrants from Northern European countries exhibit markedly higher rates compared to immigrants from Southern and Non-European countries. As a result of the small differences in participation rates between the three nationality groups, lower employment rates therefore imply higher unemployment rates. Turning to the employment level it can be seen that there are substantial differences between gender, with females exhibiting significantly lower employment rates. Additionally, native females are much likely to work part-time compared to immigrant females.

$$
- \text { TABLE } 3 \text { - }
$$

To complement the descriptive analysis of the employment performance, we now turn to the discussion of the unemployment stance of immigrants and natives. As the level of unemployment is given by the risk of becoming unemployed and the likelihood of finding a job once being unemployed, the unemployment rate as well as the duration of unemployment are shown in Table 4. In line with the results of previous tables, significant nationality group specific differences in 
unemployment rates can be observed. While unemployment rates of immigrants from Northern European countries are moderate, they are substantially higher for immigrants from Southern European countries and highest for immigrants from Non-European countries. This can be explained by the less favourable qualification structure and sectoral distribution of immigrants of the latter two nationality groups. Accordingly, their profiles do not correspond to the changing demand of the Swiss labour market, leaving a higher share of immigrants from these countries unemployed. This result is by and large reinforced by the fact that these immigrants also exhibit longer unemployment spells.

\section{- TABLE 4 -}

Finally, turning to the earnings performance of immigrant workers, Table 5 exhibits descriptive statistics on the earnings level of immigrants and natives. Three points are noteworthy. First, while immigrants are more strongly concentrated in the lower segments of the earnings distribution, the opposite holds for the higher segments. The disaggregated analysis shows that immigrants from Southern and Non-European countries are mainly responsible for the high share of immigrants in the lower earnings segments. Furthermore, substantial gender specific earnings differences can be observed, with females being concentrated mainly in the lower earnings segments, which can be explained by their inferior skill profiles compared to males.

- TABLE 5 -

\subsection{Empirical results}

In what follows, we will discuss empirical evidence on the determinants of the labour market performance for natives and immigrants (see Tables 6-9). While the analysis of the employment performance is based on the estimation of unemployment probabilities, the examination of the earnings performance is based on earnings functions. Probit estimates for the natives and immigrants are shown in Tables 6 and 7. As can be seen in Table 6, there are qualitative as well as quantitative differences between males and females. Age has a negative impact on the unemployment probability, although the effect is only significant for males. This result implies that the risk component in the determination of unemployment bears a larger weight for males than the duration component. Accordingly, the counteracting effect of the two components could explain the insignificance of the coefficient for females. A negative effect can also be observed with respect to the skill profile, although this effect is only significant for females. The insignificant effect for males can be explained by a mismatch between the skill profile on the supply side and the skill requirements on the demand side. In contrast, there is a significantly positive relationship between household residual earnings and the unemployment probability. The same holds with respect to regional economic conditions, as 
measured by the unemployment rates at the state level. While in the first case opportunity costs of working increase and accordingly search costs decrease, it is intuitive that a deterioration of the economic conditions will lead to a higher unemployment risk and an associated increase in the duration of unemployment.

\section{- TABLE $6-$}

The estimation results on unemployment probabilities for immigrants are displayed in Table 7. The main difference to natives arises with respect to the age variable. While this effect is significantly negative for native males, the opposite holds for immigrant males. This result implies that for immigrant males, the duration component bears a larger weight than the risk component. As the results in Tables 6 and 7 are derived from cross-sectional analyses, long-term unemployed are more likely to be represented in the sample, thus giving a further explanation for the positive age effect. Finally, the consideration of dummy variables for the different nationality groups in the probit regressions for immigrants reveal that the unemployment probability for immigrants from Northern Europe and Southern Europe is significantly lower than that for immigrants from Non-European countries. These results reconfirm the descriptive statistics in section 4.2.

\section{- TABLE 7 -}

After the discussion of empirical evidence on the employment performance of immigrants, we now turn to the discussion of estimation results on the earnings performance (see Tables 8 and 9). In contrast to the previous tables, the results are displayed by gender, as we used a Heckman-correction to eliminate the sample-selection bias in the earnings function of females. The results for native and immigrant males in Table 8 reveals a significantly positive effect from education, experience and employment status on the earnings level. The insignificant effect of the sector dummy can be explained by the counterbalancing effects that could arise from the heterogeneity within this variable. The insignificant effect of the duration of stay variable (YSM) is due to the long average duration of stay of immigrants that has decreased the assimilation effect markedly. Finally, the consideration of nationality group dummies shows once more that Northern Europeans outperform immigrants from Southern and Non-European countries.

\section{- TABLE $8-$}

Turning to the estimation results for females in Table 9, we find a close qualitative correspondence to males. The main difference consists of the significantly positive effect between the unemployment rate and the earnings level, which can be due to a so 'added worker'-effect. Finally, the selection correction variable (LAMBDA) is significantly negative for native and immigrant females. As a result, the observable earnings of employed females underestimates earnings of 
employable females.

\section{Policy Implications}

The analysis in this paper has shown that there is substantial need for reform of the Swiss migration policy. The prevailing policy has not only failed to achieve the goals it aimed at, but it is also subject to criticism of discrimination, as the admission of immigrant workers is based on their nationality. In what follows, we will sketch a reform alternative, which is mainly based on Golder (1997), and has already found its way into policy making, as the expert commission on migration policy made reform proposals in fall 1997 that coincided by and large with the proposal presented below.

This proposal suggests a shift to a two-circle policy. Within the first circle, analogous to the current policy, complete freedom of movement between the European Economic Area (EEA) and Switzerland is aimed at. In the second circle, where the rest of the countries can be found, immigration should be controlled by a point system. Instead of a selective, nationality-specific access of foreign workers within the existing second circle and a discriminatory access denial for foreign workers from the third circle, a point system should instead be implemented that would better account for the socio-economic characteristics of immigrants.

This new orientation of the Swiss migration policy would have mainly two advantages. First, a point system would, in contrast to a nationality-specific admission policy, allow for a direct consideration of the individual socio-economic characteristics and socio-demographic profiles of immigrants in the admission decision. Thereby, the needs of the labour market could better be accounted for. Second, the transition from a nationality-specific admission policy to a point system would also lead to a shift away from the discriminatory treatment of potential immigrants, as immigration admission would not be granted based on a specific nationality but on specific individual characteristics of applicants.

Several aspects have to be accounted for when implementing a point system. First, the allocation of points should follow the well-proven example of Canada and Australia, and be based on criteria, such as age, marital status, educational attainment, experience, language abilities, the willingness to make financial investments and create new jobs, and the prevalence of a job. The allocation of points should be guided by scarcity indicators for sectors and jobs.25 Analogous to the Canadian practice, it would be useful to grant preferential treatment to investors.

Second, within a quota system, as it already exists in Switzerland, a flexible and labour market 
oriented control of immigration could be realised. As the Swiss experience has shown, especially in the failure of the rotation policy, i.e. the presumption that there is a steady in- and outflow of immigrants, migration policy should not be used for business-cycle policy, but should instead be oriented towards the long-term structural and overall economic developments. Analogous to Canada, the government could fix a target value for a mid-term horizon, which would be subject to annual reviews and be based on the overall economic situation.

Third, the transition to a point system should also be followed by a simplification of residence permits, with a clear distinction between temporary and permanent immigration. In the case of temporary immigration, which should mainly be used for training and exchange programs for highly skilled, duration of residence should be clearly limited. Additionally, the time restriction of the permit should not allow for a deduction of any rights on a prolongation of the residence permit. Family reunification, in contrast, should be liberalised completely. In case of permanent immigration, all restrictions concerning geographical as well as job mobility should be abolished for immigrants as well as for their families. The adoption of these measures would accordingly imply the abolition of the very controversial seasonal statute.

Besides these conditions, which govern the admission criteria for immigrants, a more active integration policy should be followed. The necessity for this arises mainly from the shift in migration motives over the last decades, which has led to a substantial increase in network, family and refugee migration. As these migration moves cannot be regulated nor controlled due to humanitarian reasons, labour migration is the only policy parameter that can be used by migration policy. In order to provide all immigrants with the chance to exploit their skill potential and thus be able to contribute to the prosperity of the Swiss economy, the integration of immigrants into the Swiss economy must be improved. These considerations underline the necessity for supporting measures in the area of asylum policy. First, Switzerland must continue to adhere to its commitments under international law. Second, measures of integration policy have to be reinforced with respect to refugees who have a permanent residence permit. Third, for temporarily admitted refugees, as in the case of temporary immigration, a liberalisation of their employment opportunities should be aimed at, although this should not lead to a strengthening of their residence status.

The targeted liberalisation of mobility for goods and persons between Switzerland and the EEA within the first circle, as well as the selection of immigrant workers within the second circle, in general have to be judged positively. Especially with a view to the EEA, these measures will lead to a strengthening of the competitiveness of Swiss firms well as better access to the European labour 
market. From an economic point of view, it would be best to let market forces take over the allocation process on the European labour market. This would require, however, that market forces really work, as otherwise mis-allocations would have to be expected. As market forces are rather weak in a number of sectors in Switzerland at present, supporting measures to strengthen the liberalisation and deregulation of economic structures have to be undertaken to provide for an efficient allocation of workers.

This argument holds mainly for the stagnating and sheltered sectors of the internal economy, as sectors like the hotel and construction business, and also production, have contributed to an artificial growth of these sectors with a corresponding increase in their demand for cheap foreign workers. This development has contributed to a substantial share of foreign workers that exhibit an unfavourable skill profile and who therefore cannot be used in high-tech and competitive sectors. Intensified competition in these sectors would reinforce restructuring therein, and thus reduce the need for low-skilled workers.

\section{Conclusions}

This paper analyses the migration experience of Switzerland. The analysis centres around two main issues: the economic effects of migration and the labour market performance of immigrants. The results of this examination provide the basis for the evaluation of the effectiveness of the Swiss migration policy.

Three main results emerge from this analysis. First, the descriptive analysis has shown that there are a substantial discrepancies in the socio-demographic profiles of immigrants from different countries of origin. Immigrants from Northern European countries exhibit by far the most favourable profile. Second, as a result of the shortcomings and failures of the Swiss migration policy, which not only favours the immigration of unskilled workers but also produces a sustained sectoral misallocation of immigrants through mobility restrictions, the analysis of the economic effects of migration reveals that immigrants tend to have a negative impact on the Swiss economy. Empirical evidence shows that growth as well as structural change are negatively affected by immigration. Additionally, the cyclical buffer function of immigrants has declined substantially. The analysis of the allocational effects of migration indicates that skilled (unskilled) natives and skilled (unskilled) immigrants are complements. Evidence also revealed that there is a complementary (substitutional) relationship between capital and foreign (native) labour in Switzerland. The analysis of the distributional effects of migration in contrast indicates that there is a positive overall transfer balance effect for natives that results from migration.

Third, the analysis of the labour market performance of immigrants reveals that there is a 
substantial discrepancy in the labour market performance of immigrants from different countries of origin, as measured by the employment and earnings performance. As the estimation results reveal, immigrants from Northern European countries outperform immigrants from Southern and NonEuropean countries. Immigrants from Northern European countries even tend to outperform natives. The results are somewhat less clear if immigrants from Southern European and Non-European countries are compared, although the former tend to display a better performance.

The main conclusion that can be drawn from the analysis of these issues for the Swiss case is that the effectiveness of migration policy cannot be evaluated in isolation, as interdependencies with economic policy and politico-economic processes have to be taken into account. Migration policy is not only influenced by, but often also used as an instrument for stabilisation, growth or regional policy. One therefore has to analyse, whether migration policy is an adequate instrument to achieve these goals. Additionally, as a result of the political bargaining process, migration policy often contains numerous exceptions from the rules that can lead to inefficient outcomes. These considerations are reconfirmed by the Swiss case which shows clearly that migration policy has by and large failed to achieve the goals set out.

It must be recommended therefore that migration policy should concentrate on those issues that can be influenced effectively, namely the selection of immigrants and the integration of resident foreigners. The Swiss experience has shown that myopic policies as well as lobbying activities of cartelistic and oligopolistic industries of the domestic economy are mainly responsible for the large share of unskilled and poorly performing immigrant workers. Expanded globalisation and opening of markets as well as the strengthened internationalisation of economic relations have increased the pressure on individual economies to implement attractive locational-specific factors to remain competitive in the mobile factors - labour and capital. For this reason it seems unavoidable to push the restructuring of the Swiss economy toward a service and information society and to enhance the flexibility of the Swiss economy. If labour markets were working efficiently, much of the scope of migration policy would be eliminated by the competitive forces on these markets. From a politicoeconomic point of view, migration policy should therefore be devised simple and transparently, in order to minimise the scope and influence of special interest groups. 


\section{Appendix}

Table 1: Immigration cohorts and nationality groups (in per cent)

\begin{tabular}{|lccccccc|}
\hline Nationality Groups & \multicolumn{7}{c}{$\begin{array}{c}\text { Immigrant Cohorts } \\
\text { (Duration of stay in years) }\end{array}$} \\
& $<\mathbf{1}$ & $\mathbf{1 - 5}$ & $\mathbf{5 - 1 0}$ & $\mathbf{1 0 - 1 5}$ & $\mathbf{1 5 - 2 0}$ & $>20$ & $\begin{array}{c}\text { Immi- } \\
\text { (Tonts }\end{array}$ \\
Males & & & & & & & \\
Northern Europe & 45.7 & 58.1 & 32.2 & 18.5 & 21.6 & 33.7 & 31.8 \\
Southern Europe & 39.2 & 16.8 & 33.6 & 47.8 & 56.6 & 59.4 & 48.8 \\
Non-Europe & 15.0 & 25.1 & 34.3 & 33.6 & 21.8 & 6.8 & 19.4 \\
Age at immigration & 33 & 29 & 24 & 24 & 24 & 22 & 24 \\
Current Age & 34 & 32 & 32 & 37 & 41 & 53 & 44 \\
Females & & & & & & & \\
Northern Europe & 79.8 & 42.1 & 30.0 & 23.6 & 21.3 & 36.3 & 34.0 \\
Southern Europe & 18.6 & 27.7 & 43.8 & 42.9 & 55.4 & 54.2 & 46.1 \\
Non-Europe & 1.6 & 30.2 & 26.2 & 33.5 & 23.3 & 9.6 & 19.9 \\
Age at immigration & 27 & 26 & 26 & 23 & 22 & 23 & 24 \\
Current Age & 27 & 29 & 33 & 36 & 39 & 53 & 41 \\
\hline
\end{tabular}

Source: Golder (1999)

Table 2: Educational attainment of employed native-born and foreigners (in per cent)

\begin{tabular}{|l|rrrrrr|}
\hline $\begin{array}{l}\text { Nationality } \\
\text { Groups }\end{array}$ & $\mathbf{7}$ & $\mathbf{5}$ & $\mathbf{3}$ & $\mathbf{4}$ & $\mathbf{5}$ & $\mathbf{6}$ \\
\hline Males & & & & & & \\
Northern Europe & 4.8 & 25.7 & 14.6 & 18.5 & 30.9 & 5.5 \\
Southern Europe & 42.7 & 27.7 & 9.4 & 4.2 & 2.5 & 13.5 \\
Non-Europe & 14.8 & 29.0 & 10.7 & 8.5 & 20.1 & 16.9 \\
Foreigners & 24.7 & 27.3 & 11.3 & 9.8 & 15.3 & 11.6 \\
Swiss & 7.4 & 46.4 & 13.0 & 20.1 & 9.5 & 3.7 \\
\hline Females & & & & & & \\
Northern Europe & 7.4 & 26.5 & 26.7 & 8.2 & 19.6 & 11.5 \\
Southern Europe & 54.0 & 15.0 & 9.0 & 1.1 & 1.7 & 19.2 \\
Non-Europe & 30.7 & 28.5 & 14.3 & 5.3 & 4.9 & 16.4 \\
Foreigners & 34.3 & 21.2 & 16.2 & 4.3 & 8.4 & 15.7 \\
Swiss & 18.2 & 42.1 & 24.1 & 5.3 & 5.0 & 5.3 \\
\hline
\end{tabular}

Source: Golder (1999)

Notes: Employed: Persons aged 16 to 64

Educational attainment: 1=Compulsory education 2=Vocational education, 3=Upper-level secondary general education, $4=$ Higher vocational education, $5=$ University education, $6=$ No answer, other education 
Table 3: Participation rates and employment level for native-born and foreigners (in per cent)

\begin{tabular}{|c|c|c|c|c|c|c|c|c|}
\hline \multirow{2}{*}{$\begin{array}{l}\text { Nationality } \\
\text { Groups }\end{array}$} & \multirow[b]{2}{*}{$P R$} & \multicolumn{3}{|c|}{ Employment Level (Males) } & \multirow[b]{2}{*}{$P R$} & \multicolumn{3}{|c|}{ Employment Level (Females) } \\
\hline & & $<20$ & $20-69$ & $70-100$ & & $<20$ & $20-69$ & $70-100$ \\
\hline Northern Europe & 96.3 & & 1.9 & 98.1 & 72.3 & 6.0 & 30.0 & 64.0 \\
\hline Southern Europe & 94.1 & & 1.8 & 98.2 & 75.3 & 4.6 & 30.4 & 65.0 \\
\hline Non-Europe & 95.3 & & 3.6 & 96.4 & 71.6 & 2.6 & 23.0 & 74.4 \\
\hline Foreigners & 95.1 & & 2.2 & 97.8 & 73.6 & 4.6 & 28.5 & 66.9 \\
\hline Swiss & 90.8 & 0.8 & 3.4 & 95.8 & 68.7 & 8.2 & 35.3 & 56.5 \\
\hline
\end{tabular}

Source: Golder (1999)

Notes: $P R=$ Participation rate: Work force (employed and unemployed according to definition by SLFS)/Individuals aged 16 to 64

Table 4: Unemployment rates and duration of unemployment for native-born and foreigners (in per cent)

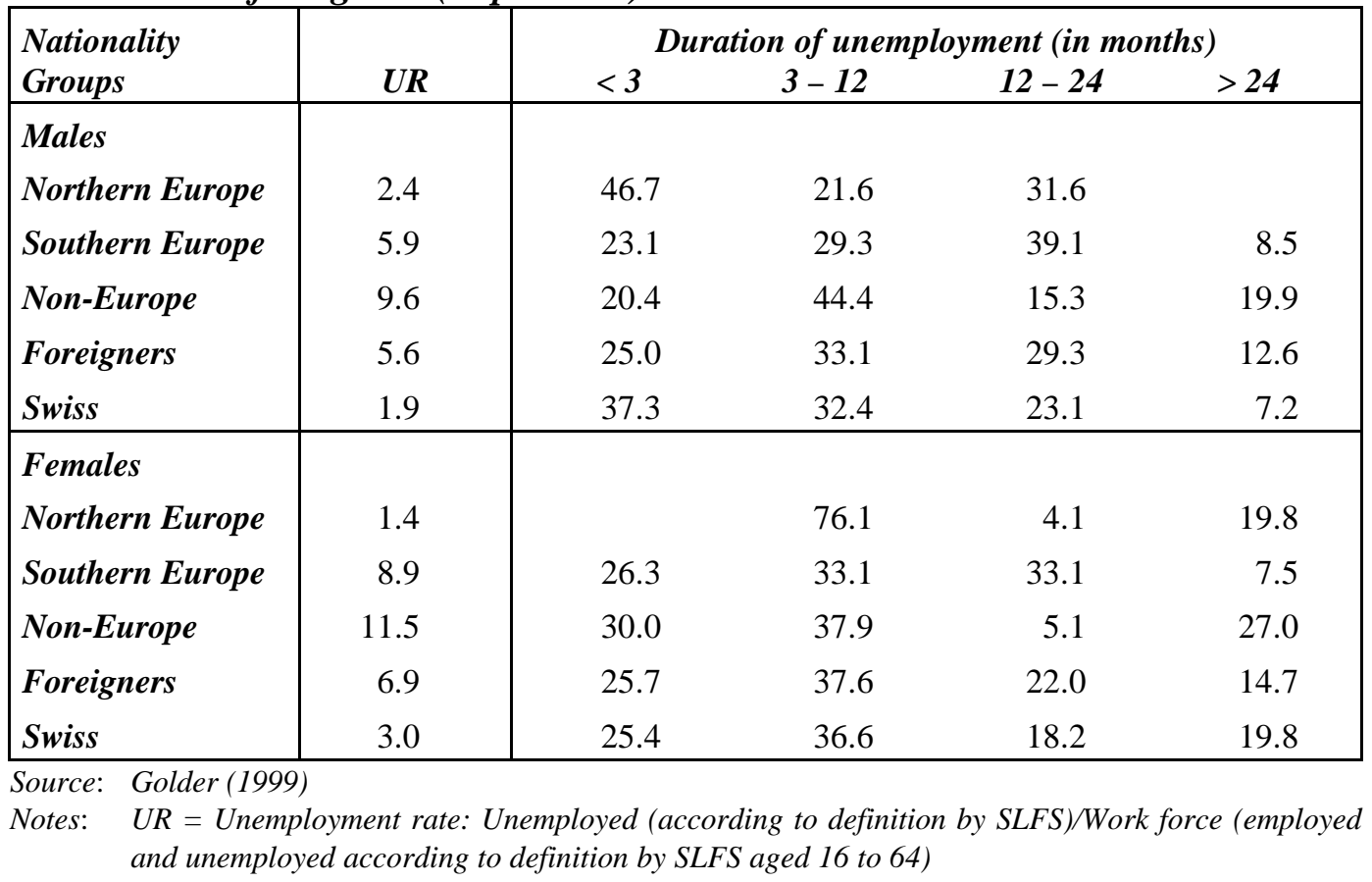


Table 5: Earnings levels for employed native-born and foreigners (in per cent)

\begin{tabular}{|lrrrrrrr|}
\hline $\begin{array}{l}\text { Nationality } \\
\text { Groups }\end{array}$ & $\mathbf{1}$ & $\mathbf{2}$ & $\mathbf{3}$ & $\mathbf{4}$ & $\mathbf{5}$ & $\mathbf{6}$ & \multicolumn{7}{c|}{ Earnings level } \\
Males & & & & & & & \\
Northern Europe & 1.6 & 0.6 & 5.1 & 18.0 & 18.4 & 36.4 & 19.9 \\
Southern Europe & 0.6 & 4.5 & 17.3 & 43.0 & 24.7 & 8.1 & 1.8 \\
Non-Europe & 1.9 & 14.8 & 23.6 & 30.9 & 14.4 & 12.6 & 1.8 \\
Foreigners & 1.2 & 5.4 & 14.9 & 33.1 & 20.7 & 17.5 & 7.2 \\
Swiss & 2.4 & 2.1 & 9.8 & 19.0 & 21.8 & 35.9 & 9.1 \\
Females & & & & & & & \\
Northern Europe & 2.3 & 7.5 & 15.5 & 25.2 & 24.5 & 22.6 & 2.4 \\
Southern Europe & 7.4 & 33.2 & 40.5 & 15.1 & 3.0 & 0.9 & \\
Non-Europe & 9.3 & 27.7 & 33.2 & 12.5 & 14.2 & 3.2 & \\
Foreigners & 6.2 & 24.4 & 31.5 & 17.6 & 11.7 & 7.9 & 0.7 \\
Swiss & 6.0 & 11.3 & 27.2 & 23.9 & 15.0 & 15.1 & 1.4 \\
\hline
\end{tabular}

Source: Golder (1999)

Notes: Employed: Persons aged 16 to 64

Earnings level in CHF: $1=\left\langle 26^{\prime} 000 \mathrm{CHF}, 2=26^{\prime} 001-39^{\prime} 000 \mathrm{CHF}, 3=39^{\prime} 001-52^{\prime} 000 \mathrm{CHF}, 4\right.$ $=52^{\prime} 001-65^{\prime} 000 \mathrm{CHF}, 5=65^{\prime} 001-78^{\prime} 000 \mathrm{CHF}, 6=78^{\prime} 001-130^{\prime} 000 \mathrm{CHF}, 7=>130^{\prime} 000$ $\mathrm{CHF}$

Table 6: Probit regression results on the unemployment probability of natives

\begin{tabular}{|c|c|c|c|c|}
\hline \multirow[t]{2}{*}{ Variables } & \multicolumn{2}{|c|}{ Males } & \multicolumn{2}{|c|}{ Females } \\
\hline & $\begin{array}{c}\text { Slope b } \\
\text { (abs. } t \text {-values) }\end{array}$ & $\begin{array}{c}\text { Marginal } \\
\text { effects }\end{array}$ & $\begin{array}{c}\text { Slope b } \\
\text { (abs. } t \text {-values) }\end{array}$ & $\begin{array}{c}\text { Marginal } \\
\text { effects }\end{array}$ \\
\hline Sample size & \multicolumn{2}{|c|}{6799} & \multicolumn{2}{|c|}{5373} \\
\hline CONSTANT & $\begin{array}{r}-2.697 * * * \\
(11.51)\end{array}$ & -0.0665 & $\begin{array}{r}-2.303 * * * \\
(8.47)\end{array}$ & -0.1025 \\
\hline$A G E$ & $\begin{array}{r}-0.009 * * * \\
(2.68)\end{array}$ & -0.0002 & $\begin{array}{r}-0.004 \\
(1.26)\end{array}$ & -0.0002 \\
\hline $\mathrm{SCH}$ & $\begin{array}{r}-0.018 \\
(1.21)\end{array}$ & -0.0004 & $\begin{array}{r}-0.053 * * * \\
(2.69)\end{array}$ & -0.0024 \\
\hline$L N \_H H I N C$ & $\begin{array}{r}0.113 * * * \\
(8.30)\end{array}$ & 0.0028 & $\begin{array}{r}0.092 * * * \\
(6.80)\end{array}$ & 0.0041 \\
\hline UNPL & $\begin{array}{r}0.106 * * * \\
(4.96)\end{array}$ & 0.0026 & $\begin{array}{r}0.100 * * * \\
(4.92)\end{array}$ & 0.0045 \\
\hline $\log -L$ & \multicolumn{2}{|c|}{-523.153} & \multicolumn{2}{|c|}{-600.047} \\
\hline Pseudo- $R^{2}$ & \multicolumn{2}{|c|}{0.251} & \multicolumn{2}{|c|}{0.234} \\
\hline
\end{tabular}


Table 7: Probit regression results on the unemployment probability of foreigners

\begin{tabular}{|c|c|c|c|c|}
\hline \multirow[t]{2}{*}{ Variables } & \multicolumn{2}{|c|}{ Males } & \multicolumn{2}{|c|}{ Females } \\
\hline & $\begin{array}{c}\text { Slope b } \\
\text { (abs. } t \text {-values) }\end{array}$ & $\begin{array}{c}\text { Marginal } \\
\text { effects }\end{array}$ & $\begin{array}{c}\text { Slope b } \\
\text { (abs. } t \text {-values) }\end{array}$ & $\begin{array}{c}\text { Marginal } \\
\text { effects }\end{array}$ \\
\hline Sample size & \multicolumn{2}{|c|}{939} & \multicolumn{2}{|c|}{640} \\
\hline CONSTANT & $\begin{array}{r}-2.977 * * * \\
(6.41)\end{array}$ & -0.2497 & $\begin{array}{r}-1.621 * * * \\
(2.74)\end{array}$ & -0.1516 \\
\hline$A G E$ & $\begin{array}{r}0.013 * \\
(1.93)\end{array}$ & 0.0011 & $\begin{array}{r}-0.006 \\
(0.64)\end{array}$ & -0.0005 \\
\hline$S C H$ & $\begin{array}{r}-0.005 \\
(0.21)\end{array}$ & -0.0004 & $\begin{array}{r}-0.029 \\
(0.80)\end{array}$ & -0.0027 \\
\hline$L N \_H H I N C$ & $\begin{array}{r}0.110 * * * \\
(4.78)\end{array}$ & 0.0093 & $\begin{array}{r}0.081 * * * \\
(2.83)\end{array}$ & 0.0076 \\
\hline UNPL & $\begin{array}{r}0.119 * * * \\
(2.97)\end{array}$ & 0.0100 & $\begin{array}{r}0.073 \\
(1.61)\end{array}$ & 0.0068 \\
\hline NTHEU_IC & $\begin{array}{r}-0.540 * * * \\
(2.69)\end{array}$ & -0.0453 & $\begin{array}{r}-0.593 * * \\
(2.29)\end{array}$ & -0.0554 \\
\hline STHEU & $\begin{array}{r}-0.455^{* * * *} \\
(2.55)\end{array}$ & -0.0382 & $\begin{array}{r}-0.337^{*} \\
(1.65)\end{array}$ & -0.0316 \\
\hline $\log -L$ & \multicolumn{2}{|c|}{-186.734} & \multicolumn{2}{|c|}{-134.175} \\
\hline Pseudo- $R^{2}$ & \multicolumn{2}{|c|}{0.336} & \multicolumn{2}{|c|}{0.311} \\
\hline
\end{tabular}


Table 8: OLS-regression results for the male earnings function (without Heckman-Correction)

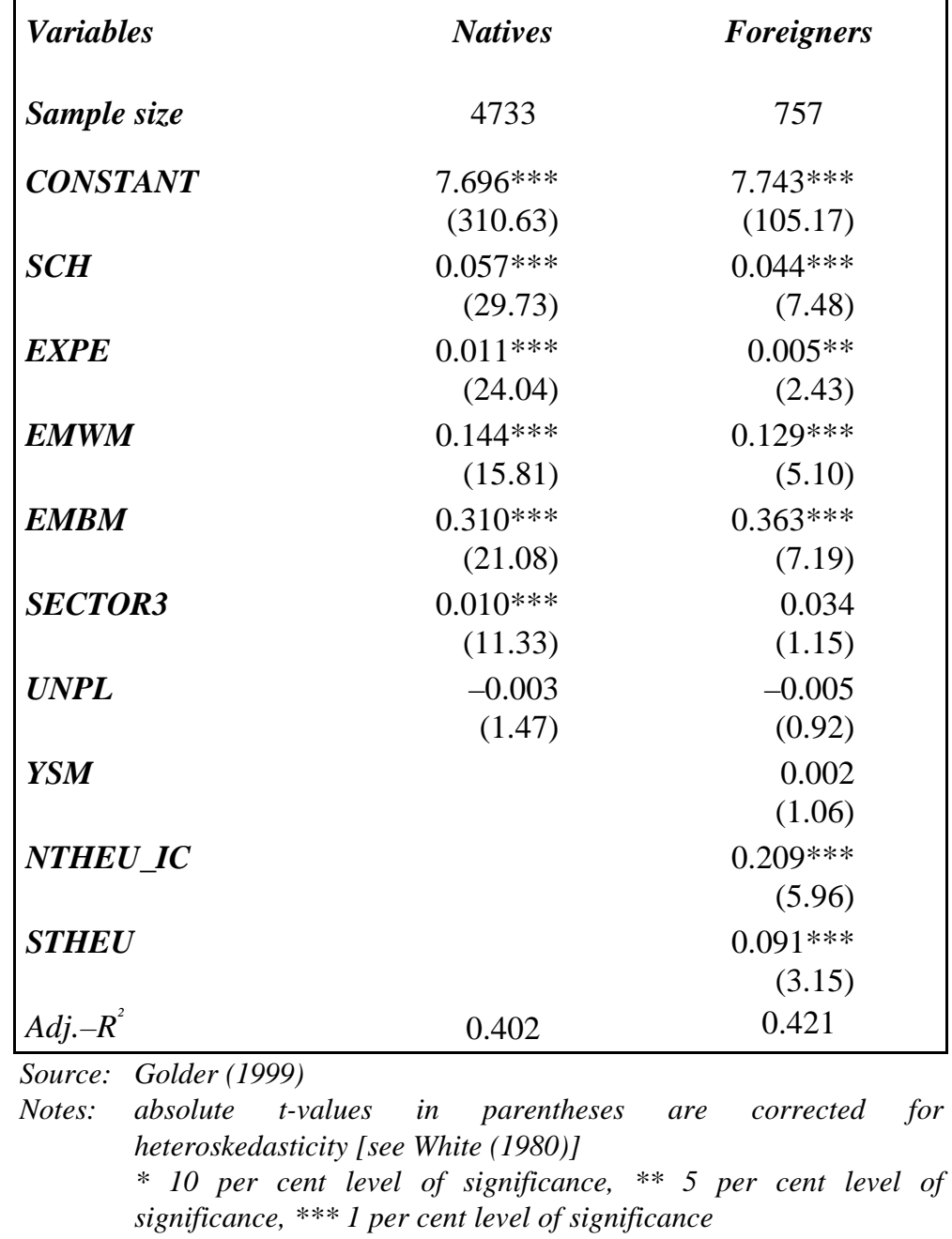


Table 9: OLS-regression results for the female earnings function (with Heckman-correction)

\begin{tabular}{|c|c|c|}
\hline Variables & Natives & Foreigners \\
\hline Sample size & 2500 & 378 \\
\hline CONSTANT & $\begin{array}{r}7.547 * * * \\
(217.99)\end{array}$ & $\begin{array}{r}7.463 * * * \\
(81.87)\end{array}$ \\
\hline$S C H$ & $\begin{array}{r}0.056 * * * \\
(19.04)\end{array}$ & $\begin{array}{r}0.044 * * * \\
(7.16)\end{array}$ \\
\hline EXPE & $\begin{array}{r}0.007 * * * \\
(11.59)\end{array}$ & $\begin{array}{r}0.006^{* * *} \\
(2.24)\end{array}$ \\
\hline$E M W M$ & $\begin{array}{r}0.094 * * * \\
(6.29)\end{array}$ & $\begin{array}{r}0.207 * * * * \\
(4.76)\end{array}$ \\
\hline EMBM & $\begin{array}{r}0.179 * * * \\
(7.18)\end{array}$ & $\begin{array}{r}0.131 * * \\
(1.85)\end{array}$ \\
\hline SECTOR3 & $\begin{array}{r}0.165^{* * * *} \\
(13.04)\end{array}$ & $\begin{array}{r}0.182 * * * * \\
(5.97)\end{array}$ \\
\hline UNPL & $\begin{array}{l}0.003 \\
(0.81)\end{array}$ & $\begin{array}{r}0.014 * \\
(1.84)\end{array}$ \\
\hline YSM & & $\begin{array}{l}0.001 \\
(0.43)\end{array}$ \\
\hline NTHEU_IC & & $\begin{array}{r}0.130 * * * \\
(2.99)\end{array}$ \\
\hline STHEU & & $\begin{array}{r}-0.043 \\
(1.05)\end{array}$ \\
\hline LAMBDA & $\begin{array}{r}-0.118 * * * \\
(7.96)\end{array}$ & $\begin{array}{r}-0.101^{* *} \\
(2.11)\end{array}$ \\
\hline $\operatorname{Adj} .-R^{2}$ & 0.270 & 0.437 \\
\hline
\end{tabular}

Source: Golder (1999)

Notes: absolute t-values in parentheses are corrected for heteroskedasticity [see White (1980)]

$* 10$ per cent level of significance, ** 5 per cent level of significance,

*** 1 per cent level of significance 


\section{Bibliography}

Becker, G. S. (1962); Investments in Human Capital: A Theoretical Analysis; Journal of Political Economy 70; 9-49.

Blattner, N. and G. Sheldon (1989); Foreign Labour, Growth and Productivity: The Case of Switzerland; in: Gordon, I. and A.P. Thirlwall (eds.); European Factor Mobility - Trends and Consequences;, MacMillan: London; 148-165.

Boehning, W. R. (1984); Studies in International Labor Migration; MacMillan: London \& Basingstokes.

Boehning, W. R. (1976); Die wirtschaftlichen Auswirkungen der Beschäftigung ausländischer Arbeitnehmer unter besonderer Berücksichtigung des Arbeitsmarktes der nachindustriellen Länder Westeuropas; in: IAB (Institut für Arbeitsmarkt und Berufsforschung) (Hrsg.); Beiträge zur Arbeitsmarkt und Berufsforschung.

Boehning, W. R. (1972); The Migration of Workers in the United Kingdom and the European Community; Oxford University Press: London.

Borjas, G. J. (1994); Immigration, Ethnic Identity, and Assimilation: The Intergenerational Transmission of Immigrant Skills; in: Giersch, H. (ed.); Economic Aspects of International Migration; Springer Verlag: Berlin; 139-154.

Borjas, G. J. (1993); The Intergenerational Mobility of Immigrants; Journal of Labor Economics 11 (1); 113-135.

Borjas, G. J. (1992); Ethnic Capital and Intergenerational Mobility; Quarterly Journal of Economics 17 (2); 123-150.

Borjas, G. J. (1991); Immigration and Self-Selection; in: Abowd, J. M. and R.B. Freeman (eds.); Immigration, Trade and the Labor Market; University of Chicago Press: Chicago; 29-76.

Borjas, G. J. (1989); Economic Theory and International Migration; International Migration Review 23 (3); 457-485.

Borjas, G. J. (1985); Assimilation, Changes in Cohort Quality, and the Earnings of Immigrants; Journal of Labor Economics 3 (4); 463-489.

Bürgenmeier, B. et al. (1992); Effects of Foreign Labour on the Production Pattern: The Swiss Case; Schweizerische Zeitschrift für Volkswirtschaft und Statistik 128 (2); 103-124.

Butare, T. and P. Favarger (1992); Analyse empirique de la Suisse; in: Bürgenmeier, B. et al. (ed.); Main d'oeuvre étrangère: Une analyse de l'économie suisse; Economica: Paris.

Cain, G. C. (1986); The Economic Analysis of Labor Market Discrimination: A Survey; in: Ashenfelter, O. and R. Layard (eds.); Handbook of Labor Economics I; Elsevier Science Publishers; 693-785.

Chiodi-Ferro, I. (1994); Migration: Eine erweiterte ökonomische Analyse unter Berücksichtigung ausserökonomischer Erkenntnisse; Dissertation Universität Zürich; Verlag Hans Schellenberg: Winterthur.

Chiswick, B. R. (1994); The Performance of Immigrants in the United States Labor Market; in: Giersch, H. (ed.); Economic Aspects of International Migration; Springer Verlag: Berlin; 95-114.

Chiswick, B. R. (1978); The Effects of Americanization on the Earnings of Foreign-born Men; Journal of Political Economy 86 (5); 897-921.

Dhima, G. (1991); Politische Ökonomie der schweizerischen Ausländerregelung; Verlag Rüegger: Chur.

Dustmann, C. (1993); Earnings adjustment of temporary migrants; Journal of Population Economics $6(2) ; 153-168$.

Expertenkommission Migration (1997); Ein neues Konzept der Migrationspolitik; Bern.

Fischer, P. A. and T. Straubhaar (1996); Einwanderung in die Schweiz - ein polit-ökonomisches Lehrstuick; in: Fassmann, H. and R. Münz (eds.); Migration in Europa: historische Entwicklung, aktuelle Trends und politische Reaktionen; Campus Verlag: Frankfurt a.M.; 183-207. 
Golder, S. M. (1999); Migration und Arbeitsmarkt - Eine empirische Analyse der Performance von Ausländern in der Schweiz; Peter Lang Verlag: Frankfurt a.M.

Golder, S. M. (1998); On the employment performance of immigrant workers: an empirical analysis for Switzerland; Discussion Papers 74; Institute for Economic Research Halle, Halle.

Golder, S. M. (1997); Die Arbeitsmarktperformance von Einwanderern in der Schweiz: Eine theoretische und empirische Analyse im Rahmen eines internationalen Vergleichs; WWZForschungsbericht 6/97 (September); Universität Basel.

Golder, S. M. and T. Straubhaar (1998); Migration to Switzerland: Some New Evidence; CEPR Discussion Paper 1791; CEPR: London.

Haug, W. (1995); Vom Einwanderungsland zur multikulturellen Gesellschaft - Grundlagen einer schweizerischen Migrationspolitik; Bundesamt für Statistik: Bern.

Hoffmann-Nowotny, H.-J. and M. Kilias (1979); Switzerland; in: Krane, R.E. (ed.); International Labor Migration in Europe; New York: Praeger; 45-62.

Kohli, U. (1997); Trade and Migration: A Production-Theory Approach; CEPR Discussion Paper 1684; CEPR: London.

Kohli, U. (1993); International Labor Mobility and Demand for Imports; Schweizerische Zeitschrift für Volkswirtschaft und Statistik 129 (3); 547-561.

Kossoudji, S. A. (1989); Immigrant Worker Assimilation: Is it a Labor Market Phenomenon?; Journal of Human Resources 24 (3); 494-527.

Kugler, P. and S. Spycher (1992); Der Einfluss des Technologiewandels auf die Struktur der Arbeitsnachfrage in der Schweiz von 1950-1988; Schweizerische Zeitschrift für Volkswirtschaft und Statistik 4; 617-641.

Maechler, A. M. (1993); Assimilation and Earnings Dynamics in Switzerland: A Comparison between Foreign Permanent Residents' and Native Workers' Earnings Profiles; Université de Genève, Institut Universitaire de Hautes Etudes Internationales; (mimeo).

OECD (1985); Economic Surveys 1985/1986; Paris: OECD.

Piore, M. J. (1979); Birds of Passage: Migrant Labor and Industrial Societies; Cambridge University Press: Cambridge.

Rossi, A. A. and T. R. Leighton (1971); Inflation in the Post-war Swiss Economy - an Econometric Study of the Interaction between Immigration and the Labor Market; Schweizerische Zeitschrift für Volkswirtschaft und Statistik 4; 761-790.

Schwarz, H. (1988); Volkswirtschaftliche Wirkungen der Ausländerbeschäftigung in der Schweiz; Basler Sozialökonomische Studien 31;. Verlag Rüegger: Grüsch.

Schwarz, H. (1985); Regionale Wirkungen der Fremdarbeiterpolitik; in: Brugger, E. and R.L. Frey (eds.); Sektoralpolitik versus Regionalpolitik; Grüsch: Rüegger; 405-419.

Sjaastad, L. A. (1962); The Costs and Returns of Human Migration; Journal of Political Economy 70; 80-93.

Straubhaar, T. and R. Weber (1994); On the Economics of Immigration: Some Empirical Evidence for Switzerland; International Review of Applied Economics 8 (2); 107-129.

Swiss Federal Statistical Office (1996); Die Schweizerische Arbeitskräfteerhebung - Konzepte, Methodische Grundlagen, Praktische Ausführung; Bundesamt für Statistik: Bern.

Taubmann, P. and M. L. Wachter (1986); Segmented Labor Markets; in: Ashenfelter, O. and R. Layard (eds.); Handbook of Labor Economics II; North-Holland; 1183-1217.

Velling, J. (1995); Wage Discrimination and Occupational Segregation of Foreign Male Workers in Germany; ZEW Discussion Paper 95-04; ZEW: Mannheim.

Velling, J. and M. Woydt (1993); Die Migrationspolitiken in ausgewählten Industrieländern - ein synoptischer Vergleich; ZEW Dokumentation; ZEW: Mannheim.

Weber, R. (1993); Einwanderung und staatliche Umverteilung: Eine ökonomische Wirkungsanalyse für die Schweiz; WWZ-Beiträge 14; Verlag Rüegger: Chur.

Weber, R. and T. Straubhaar (1994); Budget Incidence of Immigration into Switzerland: A CrossSection Analysis of the Public Transfer System; CEPR Discussion Paper 934; CEPR: London. 
Zimmermann, K. F. (1997); Die Arbeitsmarktkonsequenzen unterschiedlicher Einwanderungspolitiken; in: Sadwoski, D. and K. Pull (eds.); Vorschläge jenseits der Lohnpolitik; Frankfurt: Campus-Verlag; 297-316. 